\title{
Relationship between growth of Capitella sp. and organic enrichment of the sediment
}

\author{
Hiroaki Tsutsumi, Satomi Fukunaga, Naoko Fujita, Michiyo Sumida
}

Kumamoto Women's University, Mizuarai 2432-1, Kengun-machi, 862 Kumamoto, Japan

\begin{abstract}
Laboratory colonies of Capitella sp., which is found densely distributed in organically enriched or polluted areas, were cultured in sediments with various levels of organic matter to examine the relationship between level of sediment organic matter and growth of individuals. Growth was independent of absolute levels of sediment organic matter, but was significantly correlated with increases in the level of sediment organic matter on addition of algal powder to the sediment. These results indicate that Capitella species predominating in organically enriched areas have a physiological requirement for organic materials discharged from sources of organic enrichment, e.g. abundant growth of algae, fish farming, industrial effluent, sewage, if they are to grow normally. Although association of some Capitella species with sediment organic enrichment has been previously recognized as a reflection of their opportunistic characteristics, a physiological requirement for organic materials discharged from sources of organic enrichment may be the single factor most responsible for the concentration of Capitella species in organically enriched areas. However, it is unlikely that they can directly ingest and assimilate such organic materials. Since the additional organic materials are easily decomposed in the sediment, Capitella species may require either (1) some specific microorganisms, the levels of which increase with levels of the organic materials, or (2) certain substance(s) produced during decomposition of the organic materials.
\end{abstract}

\section{INTRODUCTION}

The association of several species of Capitella with organically enriched areas has been recognized as a reflection of the opportunistic characteristics of their life histories (Kikuchi \& Tanaka 1976, McCall 1977. Pearson \& Rosenberg 1978, Kikuchi 1979, Gray 1981, Tsutsumi \& Kikuchi 1983). In theoretical considerations of marine organisms found exclusively in habitats subject to environmental disturbance, it has been assumed that it is their opportunistic characteristics that are responsible for their occupation of such habitats. These characteristics include the ability, at the planktonic larval stage, to disperse over a wide area, so that they can escape from the adverse impact of environmental disturbance and discover new open habitats; the potential for the establishment of large populations; and a poor ability to compete with other species (Grassle \& Grassle 1974, McCall 1977). Studies of the life history of Capitella sp. I (Grassle 1980) and of Capitella sp. in Japan (Tsutsumi \& Kikuchi 1984) have shown, however, that these species of Capitella produce large eggs in small numbers and possess a rather restricted ability to disperse by means of lecithotrophic planktonic larvae, in spite of the concentration of their populations in areas subject to environmental disturbance.

Furthermore, Tsutsumi $(1987,1990)$ found that populations of Capitella sp. were maintained within each individual habitat subject to environmental disturbance by organic pollution without any reliance on widespread dispersal ability, although the populations exhibited dramatic seasonal fluctuations in size. The results of these studies suggest that the distribution of the Capitella populations was restricted to the organically enriched areas as a result of a physiological requirement for sediment with high levels of organic matter for normal growth.

The population dynamics of a single species of the sibling species complex of Capitella capitata, referred to here as Capitella sp., has been studied in Tomoe Cove, South Japan, over the past decade (Tsutsumi $1983,1987,1990)$. This cove is organically polluted by large amounts of organic material discharged from a fish farm (e.g. the residue of the food supplied to the fish and their excrement). Capitella sp. is found densely distributed only on the muddy bottom just 
below the cages used for fish farming. In the present study, Capitella sp. from Tomoe Cove was cultured in the laboratory under defined conditions in the absence of interspecific competition. The aim was to examine how the level of organic matter in the sediment influences the growth of individuals of Capitella sp. and, furthermore, to elucidate the factors most responsible for the concentration of Capitella sp. in organically enriched areas.

\section{MATERIALS AND METHODS}

Capitella sp. used in the present study were collected from the sediment on the sea bottom adjacent to the fish farm in Tomoe Cove, which is located on the northwestern corner of Amakusa Shimoshima Island, on the west coast of Kyushu, Japan $\left(32^{\circ} 32^{\prime} \mathrm{N}\right.$, $130^{\circ} 02^{\prime} \mathrm{E}$; Fig. 1). Colonies of Capitella sp. were cultured in the laboratory in plastic boxes, each of which was filled with $1.2 \mathrm{~kg}$ of sediment and $1 \mathrm{l}$ of sterilized seawater. The sediment was frozen once to kill infaunal organisms and thawed prior to the experi-

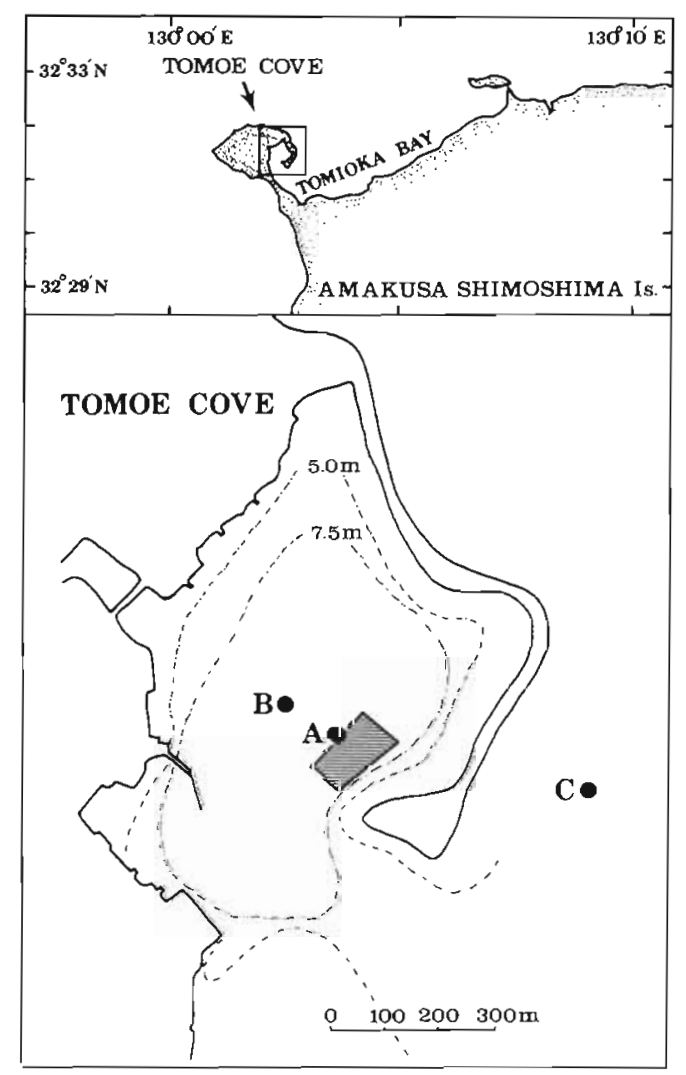

Fig. 1. Study area, Kyushu, Japan. Topography and bathymetry. (•) Locations from which samples of sediment were removed for use in experiments ments. In each box, 1000 individual pelagic larvae released from brooding females of Capitella sp. were placed, to establish a population. These larvae soon settled on the sediment and metamorphosed. Each culture of Capitella was gently aerated and kept at a constant temperature of $18^{\circ} \mathrm{C}$.

Three sediments with different levels of organic matter were prepared for laboratory culture. These were collected at 3 locations in Tomoe Cove: Location $A_{\text {, }}$ beside the fish farm; Location $B$, in the central part of the cove; and Location $C$, outside the cove. Sediment from Location A was the most organically polluted, and included a dense population of Capitella sp. By contrast, very few individuals of Capitella sp. were found in the less organically polluted sediment from Location B, and no Capitella sp. were found in the sediment from Location $\mathrm{C}$, where there is no additional supply of organic matter from the fish farm. The sediment consisted of mud at the 2 sampling locations inside the cove, and of muddy sand at the location outside the cove.

The present studies involved 2 series of experiments of 4 wk duration. In Expt 1, the colonies of Capitella sp. were reared for $4 \mathrm{wk}$ with the sediments collected at the 3 locations (Expt 1A, in sediment from Location $A_{\text {; }}$ Expt $1 B$, in sediment from Location $B_{;}$and Expt $1 C_{1}$ in sediment from Location $C_{i}$ Table 1 ), and the relationship between the level of organic matter in the sedi-

Table 1. Sampling locations and sediment protein contents for Expt 1

\begin{tabular}{|ccc|}
\hline Expt no. & $\begin{array}{c}\text { Sampling location } \\
\text { of sediment }\end{array}$ & $\begin{array}{c}\text { Protein content } \\
\text { of sediment }(\%)\end{array}$ \\
\hline 1A & Location A & 1.20 \\
1B & Location B & 0.93 \\
1C-1 & Location C & 0.43 \\
$1 \mathrm{C}-2$ & Location C & 0.38 \\
1C-3 & Location C & 0.34 \\
\hline
\end{tabular}

ment and the growth of individuals of Capitella sp. was examined. In particular, in Expt 1C, 3 replicates examined whether Capitella sp. could grow normally or not in the sediment with rather low protein content at Location C. Since field populations of Capitella sp. complete their life cycle within 4 wk at 15 to $20^{\circ} \mathrm{C}$, the duration of Expt 1 was adequate for an assessment of whether or not the various samples of sediment permit normal growth. Levels of organic matter in the sediments are expressed in terms of protein content, which is based on the organic nitrogen content (Buchanan \& Longbottom 1970). The mean protein content of the sediment during Expt 1 was $1.20 \%$ in Expt $1 \mathrm{~A}, 0.93 \%$ in Expt $1 \mathrm{~B}, 0.43 \%$ in Expt $1 \mathrm{C}-1,0.38 \%$ in Expt $1 \mathrm{C}-2$, and $0.34 \%$ in Expt $1 \mathrm{C}-3$. 
In Expt 2, to examine whether it was the level of organic matter in the sediment that controlled the growth of individuals of Capitella sp. in Expt 1, the laboratory colonies of Capitella sp. were cultured with organically enriched sediments prepared by the addition of organic matter to sediment collected outside the habitat of this species (Locations B and $C_{;}$Table 2). In this experiment, powdered green alga (Ulva pertusa) was used as an organic supplement to the sediment. About 5 or $10 \mathrm{~g}$ of powdered green algae were added to the $1.2 \mathrm{~kg}$ of sediment in each box. Consequently, the mean values of the protein content of the sediment during the period of the experiment increased from 0.90 to $1.03 \%$ in Expt $2 \mathrm{~B}$, with sediment collected at Location B. In Expt 2C, with sediment collected at Location C, 5 replicates were prepared, since the protein content of the sediment was rather lower than that of natural sediments collected at Locations $\mathrm{A}$ and $\mathrm{B}$ even after the addition of algal powder. Protein content increased from 0.43 to $0.54 \%$ in Expt $2 \mathrm{C}$ - 1 , from 0.38 to $0.50 \%$ in Expt $2 \mathrm{C}-2$, from 0.34 to $0.49 \%$ in Expt $2 \mathrm{C}-3$, from 0.34 to $0.53 \%$ in Expt $2 \mathrm{C}-4$, and from 0.34 to $0.38 \%$ in Expt $2 \mathrm{C}-5$ with sediment collected at Location C (Table 2).

Table 2. Sampling locations and increase in protein content of sediment due to addition of algal powder for Expt 2

\begin{tabular}{|cccc|}
\hline Expt no. & $\begin{array}{c}\text { Sampling } \\
\text { location of } \\
\text { sediment }\end{array}$ & $\begin{array}{c}\text { Addition of } \\
\text { algal powder } \\
(\mathrm{g})\end{array}$ & $\begin{array}{c}\text { Change in } \\
\text { protein } \\
\text { content of } \\
\text { sediment (\%) }\end{array}$ \\
\hline $2 \mathrm{~B}$ & Location B & 10 & $0.90 \rightarrow 1.03$ \\
$2 \mathrm{C}-1$ & Location C & 10 & $0.43 \rightarrow 0.54$ \\
$2 \mathrm{C}-2$ & Location C & 10 & $0.38 \rightarrow 0.50$ \\
$2 \mathrm{C}-3$ & Location C & 10 & $0.34 \rightarrow 0.49$ \\
$2 \mathrm{C}-4$ & Location C & 10 & $0.34 \rightarrow 0.53$ \\
$2 \mathrm{C}-5$ & Location C & 5 & $0.34 \rightarrow 0.38$ \\
\hline
\end{tabular}

\section{RESULTS}

Fig. 2 illustrates the size frequency distributions of individuals in the laboratory colonies of Capitella sp. in Expts $1 \mathrm{~A}, 1 \mathrm{~B}$ and $1 \mathrm{C}-1$ after culture for $4 \mathrm{wk}$. Size here is indicated by maximum thoracic width. Shaded bars indicate the frequencies of mature individuals of a given size. Individuals of Capitella sp. generally become sexually mature after they have grown to a body size of more than $0.50 \mathrm{~mm}$ in maximum width of the thoracic segments. In these experiments, only worms in Expt $1 \mathrm{~A}$ exceeded the minimum reproductively competent body size at the mode of the size frequency distribution, and only this population included sexually mature individuals with a range of
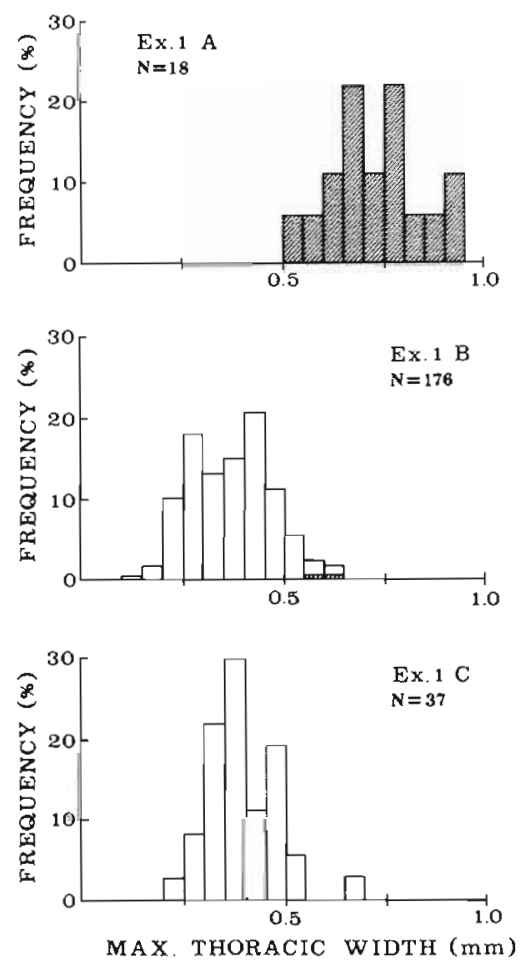

Fig. 2. Capitella sp. Size frequency distributions of individuals in laboratory colonies after culture for 4 wk in Expt 1. Shaded bars: mature individuals

body sizes from 0.50 to $0.70 \mathrm{~mm}$ in maximum thoracic width. In Expts $1 \mathrm{~B}$ and $1 \mathrm{C}$, the majority of the individuals did not reach the minimum reproductively competent body size, and almost all of them remained immature. Thus, the laboratory colonies of Capitella sp. grew normally only in the experiment with organically
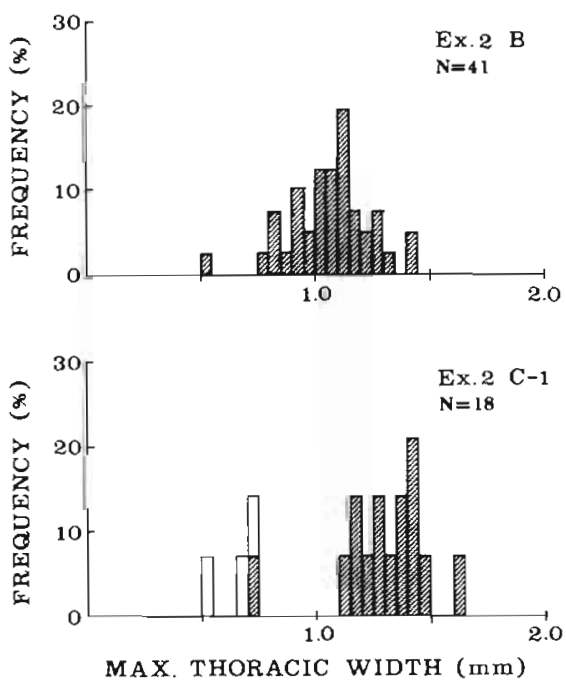

Fig. 3. Capitella sp. Size frequency distributions of individuals in laboratory colonies after culture for 4 wk in Expt 2. Shaded bars: mature individuals 
enriched sediment collected from the native habitat (Location A) of this species, although all of the colonies were cultured under defined conditions in the absence of any interspecific competition.

Fig. 3 illustrates the size frequency distributions of individuals in the laboratory colonies of Capitella $\mathrm{sp}$. in Expts $2 \mathrm{~B}$ and $2 \mathrm{C}-1$ after culturing for $4 \mathrm{wk}$. Shaded bars indicate the frequencies of mature individuals of a given size. All of the individuals in both colonies grew to body sizes far larger than the minimum reproductively competent body size $10.5 \mathrm{~mm}$ in maximum thoracic width) and were sexually mature. Thus, the growth of Capitella sp. was accelerated simply by the addition of organic matter to the sediment, even when Capitella sp. was cultured on sediment collected from outside the native habitat of this species. Expts 1 and 2 indicate that Capitella $\mathrm{sp}$, requires sediment with rather high levels of organic matter for normal growth.

The results described above indicate that the growth of Capitella sp. is not controlled simply by the level of organic matter in the sediment. Fig. 4 shows

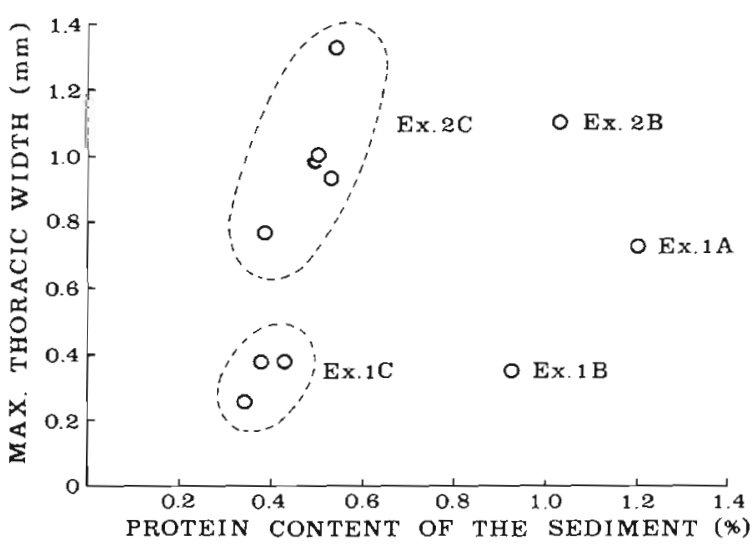

Fig. 4. Capitella sp. Relationship between mean level of organic matter in sediment during the period of the experiment and body size of members of the laboratory colonies

the relationship between the mean level of organic matter in the sediment during the period of the experiment and the body sizes of members of the laboratory colonies of Capitella sp. after culturing for $4 \mathrm{wk}_{1}$ in Expts 1 and 2. The body sizes are represented by the mode of the size frequency distributions of the laboratory colonies. Apparently, the worms grew larger as the level of organic matter in the sediment increased, if we consider results from experiments with sediments collected at the same locality, e.g. Expts $1 \mathrm{C}$ and 2C, Expts $1 \mathrm{~B}$ and $2 \mathrm{~B}$. However, no such relationship can be deduced from the results as a whole. In particular, in Expt $2 \mathrm{C}$, the worms grew to body sizes of between 0.78 and 1.00 mm in maximum thoracic width, and almost all were sexually mature adults. Nevertheless, the level of organic matter in the sediment in Expt $2 \mathrm{C}$ (protein content of 0.38 to $0.54 \%$ ) was much lower than in Expt $1 \mathrm{~B}(0.90 \%)$ in which very few individuals reached the minimum reproductively competent body size $(0.5 \mathrm{~mm}$ in maximum thoracic width) after culturing for $4 \mathrm{wk}$.

The results of Expts 1 and 2 were rearranged to permit an examination of the relationship between the increase in levels of organic matter in the sediment, due to the addition of algal powder to the sediment, and the body sizes of individuals after $4 \mathrm{wk}$ (Fig. 5).

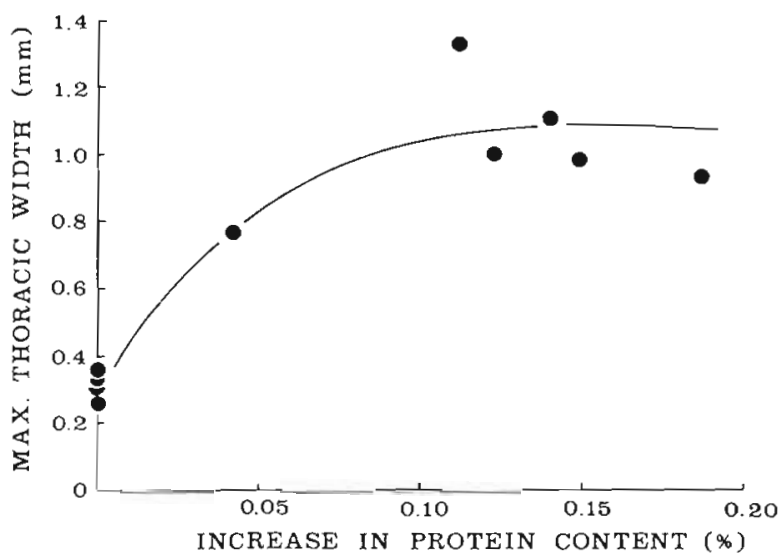

Fig. 5. Capitella sp. Relationship between increase in levels of organic matter in sediment, due to the addition of algal power, and body sizes of individuals in the laboratory colonies after culture for $4 \mathrm{wk}$

(Results of Expt $1 \mathrm{~A}$ were excluded from Fig. 5. Although the sediment at Location A was organically enriched, as a result of organic discharge from the fish farm adjacent to this sampling location, it is impossible to estimate the increase in organic matter in the sediment resulting from the organic enrichment of the sediment.) The body sizes of the colonies are again represented by the modes of the size frequency distributions. There is a significant correlation, represented by a hyperbolic tangent function, between the increase in level of organic matter in the sediment and the body sizes of the individuals. The growth of individuals was significantly correlated with the increase in level of organic matter in the sediment. In the experiments where no algal powder was added to the sediment, growth was markedly depressed and only a few individuals reached reproductively competent body size, independently of the absolute levels of organic matter in the sediment. Thus, Capitella sp. apparently needs a supply of organic matter, derived, in our experiments, from the algal powder, for normal growth. 


\section{DISCUSSION}

The relationship between the growth of Capitella species and the abundance of available food resources has been examined with laboratory colonies of Capitella sp. I (or type I) by Tenore and coworkers. Tenore $(1977,1981,1983)$ demonstrated that the growth both of individuals and of the population in the laboratory was clearly controlled by the level of nitrogen in the organic material, such as detritus derived from algae, rationed into the culture trays as food during short-term experiments over the course of several months. In long-terms experiments, over the course of $2 \mathrm{yr}$, the sizes of the populations of laboratory colonies of this species showed cyclic oscillations. Nonetheless, the population sizes of the laboratory colonies consistently reflected the amount of available nitrogen in the rations (Tenore \& Chesney 1985). These earlier results coincide with those of the present study in which growth was significantly correlated with increase in protein levels in the sediment due to the addition of algal powder (Fig. 5). Furthermore, the present results do not contradict those obtained in studies of a field population of Capitella sp. on a mud flat, where the organic enrichment of the sediment is due to the luxuriant growth of sea lettuce on the flat (Tsutsumi 1990). The increase in population densities and the increased frequencies of larger individuals in the field population reflected the increases in levels of protein in the sediment, which resulted from the addition of organic matter to the sediment from the sea lettuce that grew luxuriantly on the flat.

The present results revealed that the growth of individuals in the laboratory colonies was independent of the absolute levels of organic matter in the sediment (Fig. 4). Growth was promoted by the increase in level of organic matter in the sediment that resulted from the addition of the algal powder to the sediment (Expts 2B and 2 C). By contrast, growth was not influenced by the level of organic matter in the natural sediment that did not include discharged organic matter from the fish farm, and almost all individuals remained immature (Expts $1 \mathrm{~B}$ and $1 \mathrm{C}$ ). Therefore, these results indicate that it is the organic materials themselves, added to the sediment, that Capitella sp, requires for its normal growth. Tsutsumi $(1987,1990)$ suggested that the physiological requirement for organically enriched sediment for normal growth is the factor most responsible for the concentration of the Capitella species in organically enriched areas.

It is unlikely that the Capitella species can directly ingest and assimilate the organic materials that are added to the sediment. Since these organic materials are easily decomposed in the sediment, 2 possibilities can be suggested to explain the way in which the
Capitella species utilize them. (1) They feed on some specific microorganisms, the levels of which increase with increases in levels of organic material that is easily decomposed in the sediment. (2) They take up or absorb certain substances produced during the process of decomposition of the organic materials. The latter possibility appears the more likely. The organically enriched sediment in which the Capitella species occur is apt to be anaerobic because of the consumption of dissolved oxygen in interstitial water by degradation of organic matter in the sediment. Consequently, relatively high levels of toxic reduced sulfides, represented by hydrogen sulfide, accumulate in the sediment as a result of the activities of certain anaerobic bacteria. Although these sulfides are lethal to most invertebrates and vertebrates when present at levels of the order of parts per million (Oseid \& Smith 1974a, b, Smith et al. 1976), Cuomo (1985) showed that sulfides promote the larval settlement of Capitella sp. I, and that settlement is enhanced both in organically enriched sediment containing sulfides and under sulfidic, sediment-free conditions. These results suggest that this Capitella species does not favor organically enriched sediment with sulfides but, rather, it prefers the environments that sulfides provide. Hydrogen sulfide can be exploited for the chemosynthesis of organic matter by some bacteria. Furthermore, in the past decade, organisms with symbiotic chemoautotrophic bacteria that metabolize hydrogen sulfide have been discovered, not only in deep-sea hydrothermal vents (Cavanaugh et al. 1981, Felbeck 1981, Rau 1981) but also in reduced sediments in coastal areas (Cavanaugh 1983, 1985). Capitella species are not gutless like the organisms associated with symbiotic bacteria, and, according to Cuomo (1985), an examination of Capitella sp. I for the presence of enzymes commonly associated with chemoautotrophic symbionts by $C$. $M$. Cavanaugh indicated that adults of Capitella sp. I are not associated with chemoautotrophic symbionts. However, Capitella species are the most common component species of benthic communities in organically enriched or polluted areas throughout the world (Kitamori 1975, Pearson \& Rosenberg 1978, Kikuchi 1979, Reish 1979) and, in such places, the sediment is characterized by a reducing environment with high levels of sulfides. Followup studies on our laboratory colonies of Capitella sp. have revealed that the growth of individuals was apparently enhanced by the addition of sodium sulfide to the sediment (unpubl., to be reported elsewhere). Although the existence of symbiotic chemoautotrophic bacteria is, as yet, unknown in the Capitella species, it is possible that the concentration of Capitella species in organically enriched areas is attributable to a physiological requirement for hydrogen sulfide as an important resource for 
metabolic activity. Further investigation of the metabolic physiology of Capitella species is necessary to clarify the association of Capitella species with organic enrichment of the sediment.

Acknowledgement. This work was supported by a Grant-inAid for Scientific Research from the Ministry of Education, Science and Culture, Japan.

\section{LITERATURE CITED}

Buchanan, J. B., Longbottom, M. R. (1970). The determination of organic matter in marine muds: the effect of the presence of coral and the routine determination of protein. J. exp. Mar. Biol. Ecol. 5: 158-169

Cavanaugh, C. M. (1983). Symbiotic chemoautotrophic bacteria in marine invertebrates from sulphide-rich habitats. Nature, Lond. 302: 58-61

Cavanaugh, C. M. (1985). Symbioses of chemoautotrophic bacteria and marine invertebrates from hydrothermal vents and reducing sediments. In: Jones, $M$. L. (ed.) The hydrothermal vents of the Eastern Pacific: an overview. Bull. Biol. Soc. Wash. 6: 373-388

Cavanaugh, C. M., Gardiner, S. L., Jones, H. W., Jannasch, H. W., Waterbury, J. B. (1981). Prokaryotic cells in the hydrothermal vent tube worm Riftia pachyptila Jones: possible chemoautotrophic symbionts. Science 213: 340-342

Cuomo, M. C. (1985). Sulphide as a larval settlement cue for Capitella sp. I. Biogeochem. 1: 169-181

Felbeck, H. (1981). Chemoautotrophic potential of the hydrothermal vent tube worm, Riftia pachyptila Jones (Vestimentifera). Science 213: 336-338

Grassle, J. F., Grassle, J. P. (1974). Opportunistic life histories and genetic systems in marine benthic polychaetes. J. mar Res. 32: 253-284

Grassle, J. P. (1980). Polychaete sibling species. In: Brinkhurst, R. O., Cook, D. G. (eds.) Aquatic oligochaete biology. Plenum Press, New York, p. 25-32

Gray, J. S. (1981). The ecology of marine sediments. Cambridge University Press, New York

Kikuchi, T (1979). Some aspects of ecology, life cycle and taxonomy of the polychaete Capitella capitata, so called pollution indicator: a review. Benthos Res. 17/18: 33-51

Kikuchi, T., Tanaka, M. (1976). Some aspects on the ecology of a short-lived semelid bivalve, Theoralata (HINDS), with special reference to its opportunistic life history. Physiol. Ecol. Japan 17: 261:271

Kitamon, R. (1975). Benthos as an environmental indicator (S) with special reference to indicator species. In: The Special Committee of Japanese Ecological Society on Environmental Problems (ed.) Kankyo to seibutsu shihyo (Environ-

This article was submitted to the editor ment and indicator species). Vol. 2, Aquatic environment Kyoritsu Shuppan, Tokyo, p. 265-273

McCall, P. L. (1977). Community patterns and adaptive strategies of the infaunal benthos of Long Island Sound. J. mar Res. 35: 221--265

Oseid, D., Smith, L. (1974a). Factors influencing acute toxicity estimates of hydrogen sulfide to freshwater invertebrates. Water Res. 8: 739-746

Oseid, D., Smith, L. (1974b). Chronic toxicity of hydrogen sultide to Gammarus pseudolimnaeus. Trans. Am. Fish. Soc. 103: 819-822

Pearson, T. H., Rosenberg, R. (1978). Macrobenthic succession in relation to organic enrichment and pollution of the environment. Oceanogr. mar. Biol. A. Rev. 16: 229-311

Rau, G. (1981). Hydrothermal vent clam and tube worm 13C/ $12 \mathrm{C}$ : Further evidence of non-photosynthetic food sources. Science 213: 338-340

Reish, D. J. (1979). Bristle worms (Annelida: Polychaeta). In Hart, C. W. Fuller, S. L. H. (eds.) Pollution ecology of estuarine invertebrates. Academic Press, New York, p. $78-125$

Smith, L., Oseid, O., Olson, L. (1976). Acute and chronic toxicity of hydrogen sulfide to the fathead minnow Pimephales promelas. Environ. Sci. Technol. 10: 565-568

Tenore, K. R. (1977). Growth of Capitella capitata cultured on various levels of detritus from different sources. Limnol. Oceanogr. 22: 936-941

Tenore, K. R. (1981). Organic nitrogen and caloric content of detritus. Estuar. coast. Shelf Sci. 12: 39-47

Tenore, K. R. (1983). Organic nitrogen and caloric content of detritus III. Effect on growth of a deposit-feeding polychaete, Capitella capitata. Estuar. coast. Shelf Sci. 17. $733-742$

Tenore, K. R., Chesney (1985). The effects of interaction of rate of food supply and population density on the bioenergetics of the opportunistic polychaete, Capitella capitata (type I). Limnol. Oceanogr 30: 1188-1195

Tsutsumi, H. (1983). Preliminary report on population study of Capitella capitata (Polychaeta: Capitellidae) in Japan. Benthos Res. 24: 34-40

Tsutsumi, H. (1987). Population dynamics of Capitella capitata (Polychaeta; Capitellidae) in an organically polluted cove. Mar Ecol. Prog. Ser. 36: 139-149

Tsutsumi, H. (1990). Population persistence of Capitella sp. (Polychaeta, Capitellidae) on a mud flat subject to environmental disturbance by organic enrichment. Mar Ecol. Prog. Ser. 63: 147-156

Tsutsumi, H., Kikuchi, $T$ (1983). Benthic ecology of a small cove with seasonal oxygen depletion caused by organic pollution. Publ. Amakusa mar biol Lab. 7. 17:40

Tsutsumi, H., Kikuchi, T (1984). Study of the Life history of Capitella capitata (Polychaeta: Capitellidae) in Amakusa, South Japan including a comparison with other geographical regions. Mar. Biol. 80: 315-321

Manuscript first received: October 18, 1989

Revised version accepted: March 30, 1990 